\title{
Thekopsora minima causes blueberry rust in south-eastern Queensland and northern New South Wales
}

\author{
A. R. McTaggart • A. D. W. Geering • R. G. Shivas
}

Received: 12 March 2013 / Accepted: 28 April 2013 /Published online: 21 June 2013

(C) Australasian Plant Pathology Society Inc. 2013

\begin{abstract}
The cause of blueberry rust in eastern Australia was determined by molecular and morphological analysis as Thekopsora minima.
\end{abstract}

Keywords Large Subunit region · Naohidemyces · Pucciniales · Vaccinium

Vaccinium (Ericaceae) is host to three rust fungi, Naohidemyces vaccinii, N. fujisanensis and Thekopsora minima, which are morphologically distinguished by aecial and telial characteristics (Sato et al. 1993). The uredinial stage of blueberry rust was first recorded from Australia in 2003.

In September 2012, a specimen of rust on blueberry (Vaccinium corymbosum) from Bundaberg, Queensland, was forwarded to Biosecurity Queensland and lodged as BRIP 57654 with the DAFF Plant Pathology Herbarium. The specimen was examined microscopically. Uredinia were present on lower leaf surfaces in groups up to $5 \mathrm{~mm}$ diameter, confluent, vein limited, on necrotic spots with the corresponding upper leaf surface dark brown with a bright red diffuse border, subepidermal, erumpent, round, 100$200 \mu \mathrm{m}$ diameter, yellow (Fig. 1a). A peridium was present with a central pore. Urediniospores were subglobose, ellipsoidal to obovoid, yellow, 15-27×13-19 $\mu \mathrm{m}$, with a wall that was 1-2 $\mu \mathrm{m}$ thick and echinulate (Fig. 1b).

DNA was extracted from this specimen according to the protocol outlined by Aime (2006) using the UltraClean

A. R. McTaggart $(\varangle) \cdot$ A. D. W. Geering

Queensland Alliance for Agriculture and Food Innovation,

The University of Queensland, Ecosciences Precinct,

GPO Box 267, Brisbane, Queensland 4001, Australia

e-mail: alistair.mctaggart@gmail.com

R. G. Shivas

Plant Pathology Herbarium, Biosecurity Queensland, Department of Agriculture, Fisheries and Forestry, GPO Box 267, Brisbane, Queensland 4001, Australia
Plant DNA Isolation Kit (MoBio Laboratories, Solana Beach, CA, USA). The ITS2-LSU region was amplified with Rust2INV (Aime 2006)/LR7 (Vilgalys and Hester 1990) and nested with LROR/LR6 (Vilgalys and Hester 1990). The 28S sequence of blueberry rust (GenBank KC763340) had high identity to Thekopsora minima (HM439777 and GU355675; $99 \%$ identical over $100 \%$ query coverage) in a BLAST search. A match to Naohidemyces vaccinii was also returned with a lower sequence identity (DQ354561; $95 \%$ identical over $99 \%$ query coverage). Based on a phylogenetic reconstruction of closely related taxa from GenBank (Fig. 2), the pathogen was identified as T. minima.

The blueberry rusts in Thekopsora and Naohidemyces are heteroecious. The aecial stage of each occurs on the conifer Tsuga in the northern hemisphere. Aecial morphology is a reliable character to distinguish the two genera. Naohidemyces has aecia that are Uredo-type, with aeciospores borne singly on pedicels (Sato et al. 1993). Thekopsora differs by having aecia that are Peridermium-type, with aeciospores in chains (Sato et al. 1993). Telial morphology also differentiates the genera. The germ pores of Naohidemyces occur in the centre of the teliospores, whereas germ pores of Thekopsora are situated in the corner of each cell (Sato et al. 1993). Uredinial differentiation of Thekopsora and Naohidemyces is more subtle. Uredinia of Naohidemyces are enclosed by a peridium with conspicuous ostiolar cells, which are not present in Thekopsora (Sato et al. 1993). The size of urediniospores of species of Thekopsora and Naohidemyces on Vaccinium is not a useful taxonomic character.

Thekopsora minima was recently reported from South Africa (Mostert et al. 2010) and Mexico (Rebollar-Alviter et al. 2011) based on inoculation studies and molecular data. Australian specimens of blueberry rust held in BRIP were identified as T. minima by morphology, and in some cases by LSU sequence data, which is indicated by GenBank numbers as follows. Specimens examined: on Vaccinium corymbosum L., Brooklet, Byron Bay, New South Wales, 
Fig. 1 Thekopsora minima on Vaccinium corymbosum. a Abaxial and adaxial leaf symptoms; b Urediniospores. Scale $A=1 \mathrm{~cm} ; \mathrm{B}=10 \mu \mathrm{m}$

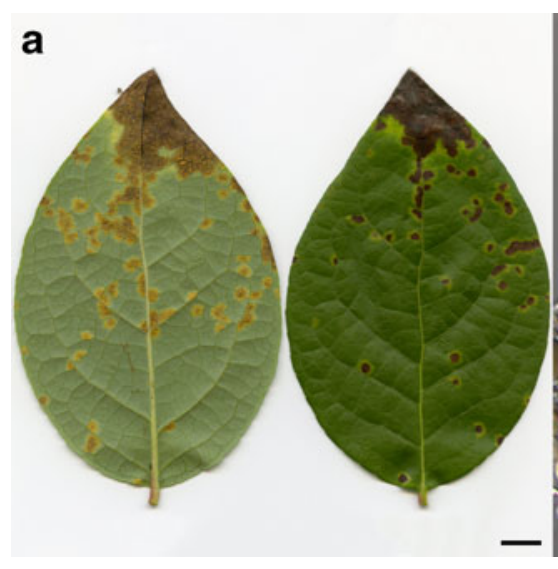

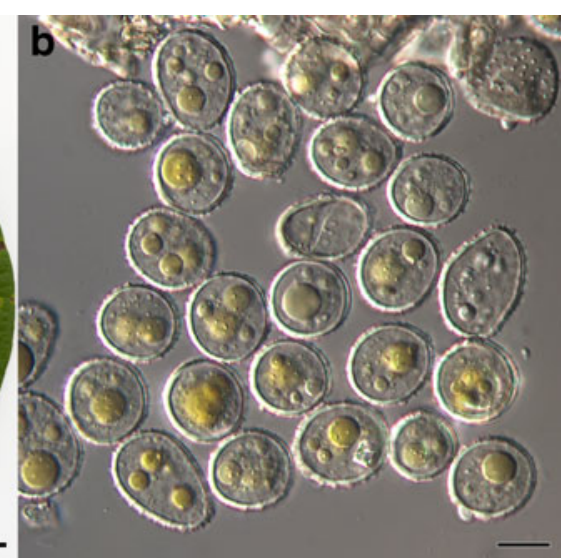

Australia, 19 February 2003, J.M. Anderson, BRIP 39896; Redlands Research Station, Cleveland, Queensland, Australia, 22 August 2008, J. Moisander, BRIP 52162, GenBank\# KC763341; Nambour, Queensland,
Australia, 15 September 2009, J. Nagle, BRIP 52832, GenBank\# KC763342.

Naohidemyces vaccinii and $N$. fujisanensis were not regarded as pathogens of blueberry by Sato et al. (1993),

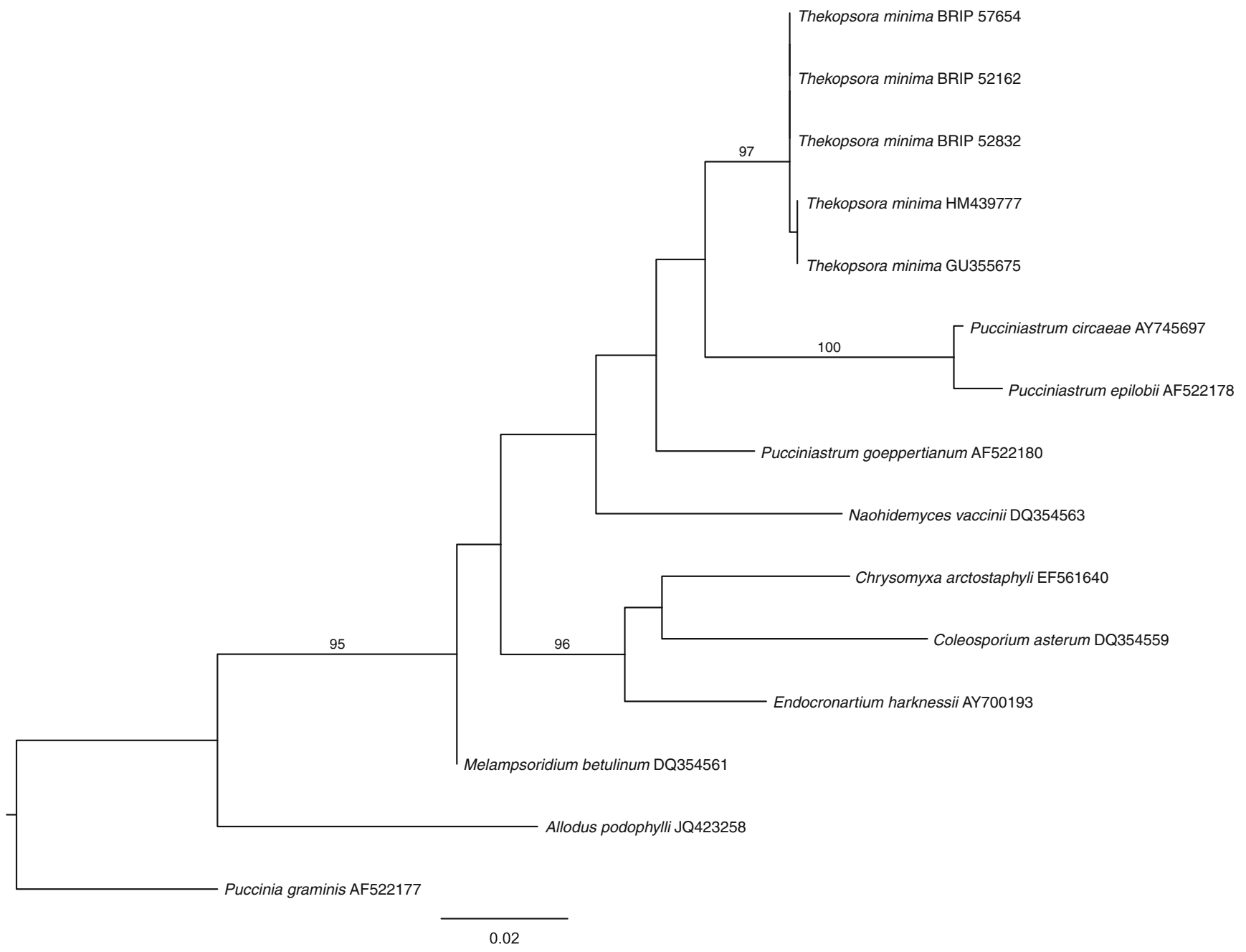

Fig. 2 Phylogram recovered from a maximum likelihood search and SPR tree improvement in PhyML with an alignment of the LSU region. aRLT values $>90 \%$ shown above nodes 
although they infected other Vaccinium species. Naohidemyces is not recorded in Australia.

Acknowledgments This work was partly funded by the Australian Biological Resources Study, grant number RFL212-33.

\section{References}

Aime MC (2006) Toward resolving family-level relationships in rust fungi (Uredinales). Mycoscience 47:112-122
Mostert L, Bester W, Jensen T, Coertze S, van Hoorn A, Le Roux J, Retief E, Wood A, Aime MC (2010) First report of leaf rust of blueberry caused by Thekopsora minima on Vaccinium corymbosum in the Western Cape, South Africa. Plant Dis 94:478-478

Rebollar-Alviter A, Minnis AM, Dixon LJ, Castlebury LA, RamírezMendoza MR, Silva-Rojas HV, Valdovinos-Ponce G (2011) First report of leaf rust of blueberry caused by Thekopsora minima in Mexico. Plant Dis 95:772-772

Sato S, Katsuya K, Hiratsuka Y (1993) Morphology, taxonomy and nomenclature of Tsuga-Ericaceae rusts. Trans Mycol Soc Jpn $34: 47-62$

Vilgalys R, Hester M (1990) Rapid genetic identification and mapping of enzymatically amplified ribosomal DNA from several Cryptococcus species. J Bacteriol 172:4238-4246 